\title{
Investigating tax culture of the tax payers of the Iranian Tax Administration
}

\author{
Professor Dr. Sorush Niknamian \\ Board Member of Weston A Price Foundation, Washington Dc, USA \\ E-mail: so.niknamian@gmail.com
}

\begin{abstract}
The purpose of this study is to investigate the tax culture of tax payers in the Iranian Tax Administration. This was an applied-descriptive survey study. The statistical population was divided into three groups according to the share of tax revenue in 2017 and 12 provinces from 31 provinces selected by cluster and quota sampling. The sample size was calculated using the Cochran formula for a large population of 690 people for each group. A questionnaire was used to collect data. The content validity of the questionnaires was confirmed by the experts and the construct validity was verified by factor analysis. The reliability of the questionnaires was also calculated using Cronbach's alpha (0.925). The data were analyzed using correlation coefficient, mean test and factor analysis using the Structural Equation Modeling in LISREL. The results showed that each of the components of the tax culture of the tax payers was higher than satisfactory.
\end{abstract}

Key words: Culture, Tax culture, Tax payers

\section{Introduction}

Tax culture is a mixture of attitudes, beliefs and actions taken by people regrding the tax system and we learn about what is our duty considering the tax system and what role should we play. Financing government expenditures through tax revenues is one of the issues that has been considered by government in recent years in developing countries, including Iran (Mahboubi et al., 2011). Efforts to create a leading and strong tax culture in the country can have a significant impact on reducing costs, increasing government revenues and creating effective controls that increase social justice and welfare. Therefore, development of the tax system of each country is considered as the main symbols of its comprehensive and balanced development. The key role of culture is not solely limited to implementation of tax laws. In all democratic societies, the rate of growth and awareness of the laws and its consequences will make the system more effective. To this end, policymakers of these types of societies believe in a direct link between culture and law (Salehi et al., 2014).

With the creation of a coherent tax system, government reliance on oil revenues is reduced and a large portion of its current and developmental costs are provided. In this context, it seems necessary to develop and promote a tax culture. However, for cultural development in all societies, one cannot predict a fixed criterion (because there are many factors in the cultural impact of each society separately), but what is common in all societies, is the reaction and influence of laws from the culture of each society (Shamsuddini and Shahraki, 2016). Although the rule of law cannot be separated from people's thinking about the law, and customs are usually used in the creation of laws, it should be considered that in dealing with important phenomena, coordinating people attitudes of this specific term requires planning and futurism (Hassan Ghayamety Arani, 2013).

Iran is a low-income and low-tax country among the countries of the world in terms of tax effort (Lee Blanc et al., 2008), so that, the escape and tax avoidance is a social norm (Salehi et al., 2014). 
All this suggests an accurate and important point: the state of our tax culture is not in a good condition, and our society suffers from the weakness of the country's culture. Therefore, the main question of the present research is as follows: What is the status of the components of the tax culture of the taxpayers in the studied population?

\section{Research background}

A summary of some of the internal and external studies related to the title of research is presented in Table 1 .

Table 1: Summary of internal study results

\begin{tabular}{|c|c|c|}
\hline Author & title & results \\
\hline $\begin{array}{l}\text { Masihi and Mohammad Nejad } \\
\text { High Earth (2015) }\end{array}$ & $\begin{array}{l}\text { The study of factors affecting } \\
\text { tax culture from the viewpoint } \\
\text { of taxpayers and tax experts }\end{array}$ & $\begin{array}{l}\text { Based on the results of his } \\
\text { research, positive attitude } \\
\text { towards the job and the } \\
\text { appropriateness of the business } \\
\text { environment of the tax brokers, } \\
\text { enforcement of guarantees and } \\
\text { respect of the clients and } \\
\text { protection and safeguarding of } \\
\text { their employees are among the } \\
\text { factors influencing the culture } \\
\text { Taxes. }\end{array}$ \\
\hline Porostat (2013) & $\begin{array}{l}\text { Prioritizing the Factors } \\
\text { Affecting Tax Compliance with } \\
\text { the Multi-criteria Techniques } \\
\text { Approach }\end{array}$ & $\begin{array}{l}\text { The results of the research } \\
\text { showed that according to the } \\
\text { hierarchical analysis method, } \\
\text { public trust in tax allocation and } \\
\text { consumption, honesty and sense } \\
\text { of responsibility of taxpayers } \\
\text { and appropriate tax culture (tax } \\
\text { belief among the general } \\
\text { population) are respectively the } \\
\text { most important factors affecting } \\
\text { tax compliance. }\end{array}$ \\
\hline Hassan Gayamati Arani (2013) & $\begin{array}{l}\text { Examining the promotion of tax } \\
\text { culture from the employee's } \\
\text { perspective }\end{array}$ & $\begin{array}{l}\text { There is a meaningful } \\
\text { relationship between } \\
\text { management factors and the } \\
\text { promotion of tax culture as a } \\
\text { result of increased tax } \\
\text { collection. Simplicity and } \\
\text { comprehensiveness of laws and } \\
\text { regulations, the implementation } \\
\text { of modern procedures, the } \\
\text { availability of equipment and } \\
\text { administrative facilities, and } \\
\text { continuing training, are effective } \\
\text { in developing and promoting a } \\
\text { tax culture. }\end{array}$ \\
\hline
\end{tabular}




\begin{tabular}{|c|c|c|}
\hline Lashkarzadeh and Azizi (2011) & $\begin{array}{l}\text { Identification of some effective } \\
\text { factors on promoting tax culture } \\
\text { in Iran }\end{array}$ & $\begin{array}{l}\text { The results of the test showed } \\
\text { that: 1. Level of tax culture } \\
\text { among the population is below } \\
\text { the average; 2. Lack of } \\
\text { knowledge of the people about } \\
\text { the importance of paying taxes is } \\
\text { one of the factors inhibiting tax } \\
\text { culture; 3. Simplifying the texts } \\
\text { of tax laws and rationalizing the } \\
\text { stages of obtaining taxes have an } \\
\text { impact on the promotion of tax } \\
\text { culture; } 4 \text {. Education of people } \\
\text { with tax laws and regulations } \\
\text { reduces diagnosis and promotes } \\
\text { tax culture; 5. Increasing the } \\
\text { equity and functioning of the tax } \\
\text { organization has an impact on } \\
\text { promoting tax culture; and } 6 \\
\text { Honesty and the sense of } \\
\text { responsibility of tax payers are } \\
\text { one of the factors promoting tax } \\
\text { culture. }\end{array}$ \\
\hline Qiblah (2007) & $\begin{array}{l}\text { Tax culture and its review in the } \\
\text { community of doctors in } \\
\text { northern Tehran and } \\
\text { presentation of behavioral } \\
\text { model }\end{array}$ & $\begin{array}{l}\text { There is no meaningful } \\
\text { difference between the tax } \\
\text { culture and the level of expertise } \\
\text { of physicians }\end{array}$ \\
\hline Sheydayi (2007) & $\begin{array}{l}\text { Examining the ways to promote } \\
\text { tax culture with emphasis on the } \\
\text { business sector }\end{array}$ & $\begin{array}{l}\text { The results of a survey conducted } \\
\text { on } 195 \text { of the tax payers in West } \\
\text { Tehran indicate that there is a } \\
\text { relationship between the need to } \\
\text { pay taxes, tax laws, how taxes are } \\
\text { levied, tax officials, and the tax } \\
\text { culture. }\end{array}$ \\
\hline Litina and Paulius (2016) & $\begin{array}{l}\text { Corruption, tax evasion and } \\
\text { social values }\end{array}$ & $\begin{array}{l}\text { Standard deterrent policies } \\
\text { cannot eliminate multiple } \\
\text { balances, instead policies that } \\
\text { impose a strong moral tax on } \\
\text { taxes and corrupt politicians can } \\
\text { lead to a unique balance. }\end{array}$ \\
\hline Pakarang Chuenjit (2014) & $\begin{array}{l}\text { Taxation culture and definitions } \\
\text { and conceptual methods for tax } \\
\text { management }\end{array}$ & $\begin{array}{l}\text { Regarding compliance with tax } \\
\text { laws, tax management and tax } \\
\text { reform have been assessed for } \\
\text { taxpayers and taxgivers. The } \\
\text { results obtained from these } \\
\text { studies show that differences in } \\
\text { tax culture lead to different } \\
\text { consequences for tax collecting. }\end{array}$ \\
\hline Quartet and Prince (2014) & $\begin{array}{l}\text { The dynamic behaviors of tax } \\
\text { evasion }\end{array}$ & $\begin{array}{l}\text { Over the past two decades, new } \\
\text { approaches (eg laboratory }\end{array}$ \\
\hline
\end{tabular}




\begin{tabular}{|l|l|l|}
\hline & & $\begin{array}{l}\text { experiments, material-based } \\
\text { modeling, etc.) have been } \\
\text { developed with the viewpoints of } \\
\text { how to increase behavioral } \\
\text { dynamics or avoid tax evasion. In } \\
\text { addition, there is empirical } \\
\text { evidence that supports the role of } \\
\text { such interaction dynamics. }\end{array}$ \\
\hline Bai-Alddar et al. (2013) & $\begin{array}{l}\text { Sfter controlling the factors } \\
\text { mentioned above, a subset of the } \\
\text { influential cultural values that } \\
\text { are stipulated by the levels of } \\
\text { irregularity to predict tax } \\
\text { evasion. The findings suggest } \\
\text { that there are a number of } \\
\text { experimental empirical and } \\
\text { experimental research concepts. }\end{array}$ \\
\hline
\end{tabular}

\section{Methodology}

The present research was a quantitative exploratory applied descriptive case study. The statistical population was selected from the tax payers of Iranian tax administration and random cluster sampling was used to select participants from each province. Since the size of the statistical population was large, it was not possible to examine the ideas of the entire statistical population in terms of time and cost. Therefore, cluster sampling was done as follows:

In the first stage, the statistical population (31 provinces of the country) was divided into three groups of provinces with high, medium and low tax revenue, based on the tax revenue share of each province to total tax revenues of the country in 2017 . The first group devoted $48 \%$, the second group $23 \%$ and the third group 29\% of the total tax revenue. According to the quota sampling, 7 provinces from the first group, 2 provinces from the second group and 3 provinces from the third group were selected randomly.

Accordingly, due to the large statistical population and the standard deviation of 0.67 and accuracy of 5\%, the sample size is calculated for each group from the below formula:

$$
n=\left(\frac{Z_{\frac{\alpha}{2}} \times \sigma}{e}\right)^{2}=\left(\frac{1.96 \times 0.67}{0.05}\right)^{2}=690
$$

For this purpose, 690 people were selected as a sample group. Finally, in order to prevent the participant fall, to ensure delivering the questionnaires, a sample size of 800 persons per group was determined.

In the present study, both field and library methods were used to collect data. The research tool was a researcher-made tax culture questionnaire whose face and conceptual validity was verified by the experts. Then, for measuring the reliability of the questionnaire, Cronbach's alpha was used and it was 0.925 , which is a relatively good reliability.

The results of fitting the pattern of each of the model structures using the confirmatory factor analysis are shown in Table 3. According to the presented indices, it can be said that the model of measurements has appropriate fit. The results of the path coefficients and the t-Value are shown in Table 2. 
Table 2: Standard factor burden and t values for tax culture items

\begin{tabular}{|c|c|c|c|c|}
\hline value-p & $\mathrm{t}$ value & $\begin{array}{c}\text { Standardized factor } \\
\text { loa }\end{array}$ & Items & Construct \\
\hline & - & 0.348 & 1 & \multirow{11}{*}{ Tax culture } \\
\hline 0.000 & 8.112 & 0.199 & 2 & \\
\hline 0.000 & 15.541 & 0.661 & 3 & \\
\hline 0.000 & 16.079 & 0.762 & 4 & \\
\hline 0.000 & 16.333 & 0.824 & 5 & \\
\hline 0.000 & 16.293 & 0.813 & 6 & \\
\hline 0.000 & 16.45 & 0.857 & 7 & \\
\hline 0.000 & 16.217 & 0.794 & 8 & \\
\hline 0.000 & 16.157 & 0.78 & 9 & \\
\hline 0.000 & 15.607 & 0.672 & 10 & \\
\hline 0.000 & 14.86 & 0.569 & 11 & \\
\hline
\end{tabular}

Table 3: The results of fitness of pattern of tax culture

\begin{tabular}{|c|c|c|}
\hline Obtained value & Accepted value & index \\
\hline $0 / 076$ & $\begin{array}{l}\text { Equal or lower than } \\
0 / 08\end{array}$ & Root Mean Square Error (RMSEA) \\
\hline $4 / 212$ & $\begin{array}{c}\text { Equal or lower than } \\
5\end{array}$ & Normalized Chi-Square (CMIN / DF) \\
\hline $0 / 916$ & $\begin{array}{c}\text { Equal or lower than } \\
0 / 9\end{array}$ & Goodness Fitness Index (GFI) \\
\hline 0/906 & $\begin{array}{l}\text { Equal or lower than } \\
0 / 9\end{array}$ & Improved goodness Fitness Index (AGFI) \\
\hline $0 / 922$ & $\begin{array}{c}\text { Equal or lower } \\
0 / 9 \text { than }\end{array}$ & Adaptive fit index (CFI) \\
\hline $0 / 921$ & $\begin{array}{l}\text { Equal or lower } \\
0 / 9 \text { than }\end{array}$ & Normative Fitness Index (NFI) \\
\hline $0 / 917$ & $\begin{array}{l}\text { Equal or lower } \\
0 / 9 \text { than }\end{array}$ & Tucker Lewis Index (TLI) \\
\hline $0 / 922$ & $\begin{array}{c}\text { Equal or lower } \\
0 / 9 \text { than }\end{array}$ & Incremental fitting index (IFI) \\
\hline
\end{tabular}

Considering that the ratio of chi-square is less than 5, and the RMSEA index is less than 0.08, it shows that the model has a good fit. Other indicators such as the NFI, the NNFI, the IFI, the CFI were used and values above 0.9 of these indicators suggested a very good fit of model compared to other models.

In this research, after data editing, coding and entering of data, descriptive and inferential statistical methods were used to analyze data in SPSS and Amos software.

Normality of data: According to the central limit theorem, this assumption is adhered to for single-variable data and the present research data are normal. 
Research findings: Description of the tax culture of the taxpayer This variable is comprised of 117 -point items. The descriptive statistics of this variable are presented in Table 4. For a better interpretation, the mean of "Abbas Bazargan et al.", which is presented in Table 5 (Bazargan et al., 1999) was used. Based on the empirical mean (4.67) and according to Abbas Bazargan et al., it can be concluded that the tax culture variable was more than satisfactory.

Table 4: Descriptive Statistics of Taxpayer Culture

\begin{tabular}{ccccccc}
\hline Maximum & Minimum & SD & mode & Median & M & $\mathrm{N}$ \\
\hline 5.44 & 3.00 & 0.35 & 5.00 & 4.72 & 4.67 & 2220 \\
\hline
\end{tabular}

Table 5: Scale of Bazargan et al

\begin{tabular}{ccccccc}
\hline unfavorable & boundary & favorable & Very favorable & good & Strong & $\begin{array}{c}\text { Very } \\
\text { strong }\end{array}$ \\
$3 / 00$ كنر & $3 / 01-3 / 49$ & $3 / 51-3 / 99$ & $4 / 01-5 / 59$ & $5 / 61-5 / 99$ & $6 / 01-6 / 49$ & $6 / 51-6 / 99$ \\
\hline
\end{tabular}

Description of Components of Taxpayers Culture The descriptive information of the components of tax culture, including mean, median, mode, standard deviation, minimum and maximum, is presented in Table 6. For a better interpretation, the mean of the scale of "Abbas Bazargan et al.", is presented in Table 7 (Bazargan et al., 1999) was used.

Based on the empirical mean and the scale of "Abbas Bazargan et al.", it can be concluded that the components of tax culture of the tax payers are more than satisfactory.

Table 6: Descriptive Statistics of the components of Tax culture among tax payers

\begin{tabular}{cccccccl}
\hline Maximum & Minimum & SD & Mode & Median & M & N & Variable \\
\hline 6.00 & 2.40 & 0.51 & 5.00 & 4.80 & 4.62 & $2220 \begin{array}{l}\text { Filing in the tax } \\
\text { unit }\end{array}$ \\
\hline 6.00 & 2.75 & 0.46 & 5.00 & 5.00 & 4.75 & $2220 \begin{array}{l}\text { Submission of the } \\
\text { tax return on time }\end{array}$ \\
\hline 5.83 & 2.17 & 0.40 & 5.00 & 4.83 & 4.75 & 2220 & $\begin{array}{l}\text { Timely payment of } \\
\text { taxes }\end{array}$ \\
\hline
\end{tabular}

Table 7: Scale of Bazargan et al

\begin{tabular}{ccccccc}
\hline unfavorable & boundary & favorable & Very favorable & good & Strong & $\begin{array}{c}\text { Very } \\
\text { strong }\end{array}$ \\
$3 / 00>$ & $3 / 01-3 / 49$ & $3 / 51-3 / 99$ & $4 / 01-5 / 59$ & $5 / 61-5 / 99$ & $6 / 01-6 / 49$ & $6 / 51-6 / 99$ \\
\hline
\end{tabular}

Investigating the Status of Taxpayers culture and its Components in the population

The main question: What is the status of the tax culture of taxpayers in the studied population? 
H0: The tax culture of taxpayers in the studied population is not in desirable condition.

H1: Tax culture of taxpayers in the studied population is in a favorable situation.

As shown in Table 8 , given that the significance level of the test $(0.000)$ is less than the significant level (0.05), hypothesis one cannot be ruled out. In other words, according to the average obtained for this variable and the index of Abbas Bazargan et al., it can be said that the status of tax culture in the studied population is more than satisfactory.

Table 8: The status of tax culture of taxpayers in the studied population

\begin{tabular}{crrr}
\hline \multicolumn{2}{c}{$3 / 5=$ Theoretical mean } & SD & M \\
\cline { 1 - 2 } & t value & & \\
\hline 0.000 & 158.28 & 0.35 & 4.67 \\
\hline
\end{tabular}

Sub-questions: What is the status of the components of tax culture in the studied population?

As shown in Table 9, given that the significance level of the test $(0.000)$ is less than the significant level (0.05) in each of the components of the tax culture, so the hypothesis one cannot be ruled out. In other words, according to the mean obtained for this variable and the index of Abbas Bazargan et al., it can be said that the status of each of the components of tax culture in the studied population is more than satisfactory.

Table 9: Status of tax culture components in the studied population

\begin{tabular}{ccccc}
\hline \multicolumn{2}{c}{$3 / 5=$ Theoretical mean } & SD & M & $\begin{array}{c}\text { Tax culture } \\
\text { components }\end{array}$ \\
\hline Sig & t value & fom & 4.61 & filing \\
\hline 0.000 & 102.82 & 0.51 & 4.75 & $\begin{array}{c}\text { On time delivering of } \\
\text { tax return }\end{array}$ \\
\hline 0.000 & 129.02 & 0.45 & On-time tax payment \\
\hline 0.000 & 148.33 & 0.40 & 4.75 & \\
\hline
\end{tabular}

Evaluation of Structural Equation Modeling Results

In this section, using the structural equation modeling approach, we examine the suggested model of research and the relationship between the components of the tax culture of the tax payers, the results of which are discussed below.

Table 10: Indicators of fitting of the tax culture model for payers

\begin{tabular}{|c|c|c|}
\hline $\begin{array}{c}\text { obtained } \\
\text { value }\end{array}$ & Accepted value & indicator \\
\hline $0 / 063$ & $\begin{array}{c}\text { Equal or lower than } \\
0 / 08\end{array}$ & (RMSEA) \\
\hline $2 / 457$ & $\begin{array}{c}\text { Equal or lower than } \\
3\end{array}$ & (CMIN/DF) \\
\hline
\end{tabular}




\begin{tabular}{|c|c|c|}
\hline $\begin{array}{l}\text { obtained } \\
\text { value }\end{array}$ & Accepted value & indicator \\
\hline $0 / 944$ & $\begin{array}{l}\text { Equal or lower than } \\
0 / 9\end{array}$ & (GFI) \\
\hline $0 / 893$ & $\begin{array}{l}\text { Equal or lower than } \\
0 / 9\end{array}$ & (AGFI) \\
\hline $0 / 982$ & $\begin{array}{l}\text { Equal or lower than } \\
0 / 9\end{array}$ & (CFI) \\
\hline $0 / 971$ & $\begin{array}{l}\text { Equal or lower than } \\
0 / 9\end{array}$ & (NFI) \\
\hline $0 / 970$ & $\begin{array}{l}\text { Equal or lower than } \\
0 / 9\end{array}$ & (TLI) \\
\hline $0 / 982$ & $\begin{array}{l}\text { Equal or lower than } \\
0 / 9\end{array}$ & (IFI) \\
\hline
\end{tabular}

Table 11: Standard load factor and t values for tax culture components

\begin{tabular}{ccclc}
\hline value-p & value t & Standardized factor load & \multicolumn{1}{c}{ variable } & construct \\
\hline $0 / 000$ & 23.644 & 0.634 & Filing in the tax unit & \\
\cline { 1 - 3 } $0 / 000$ & 24.272 & 0.741 & $\begin{array}{l}\text { Submission of the tax return on } \\
\text { time }\end{array}$ & \\
\cline { 1 - 3 } & - & 0.768 & Timely payment of taxes & \\
\hline
\end{tabular}

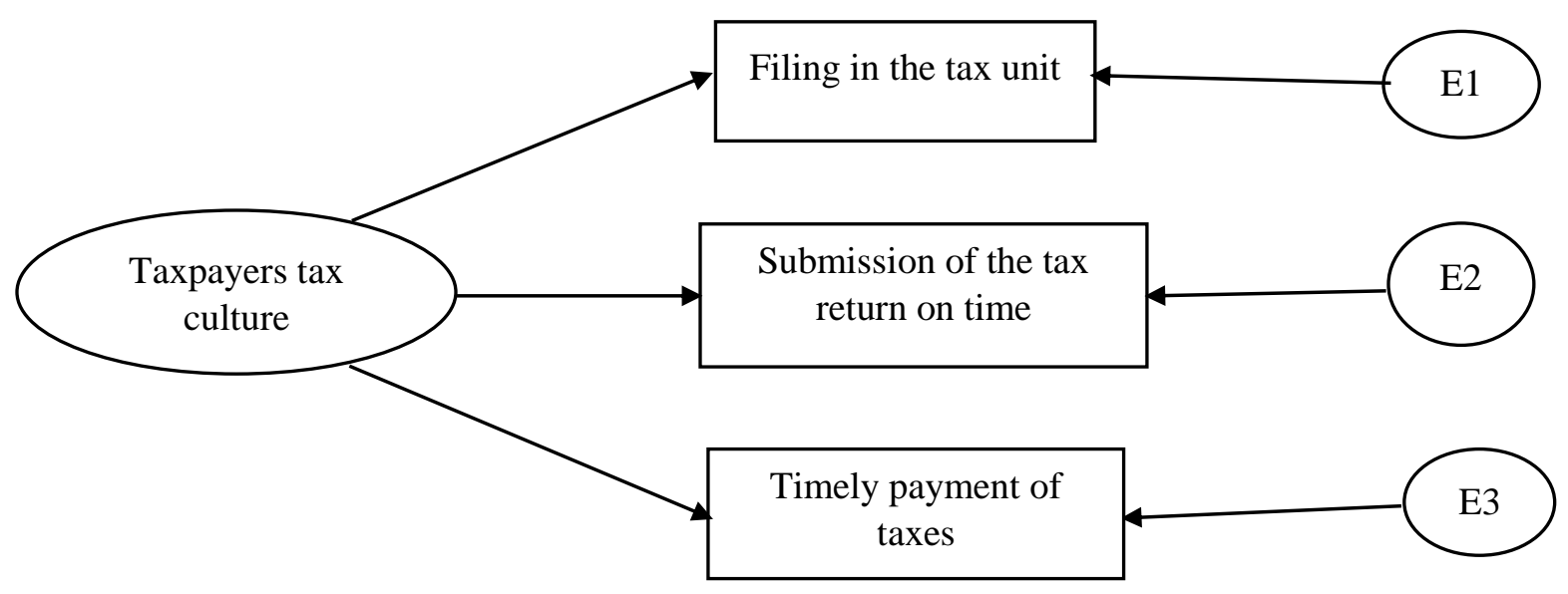

Figure 1: The results confirmatory factor analysis of the tax culture of the taxpayers (standardized load factor)

Ranking tax culture components in the studied population: H0 The ranks are similar.: H1 The ranks are different. As shown in Table 14, given that the p value of the test $(0.000)$ is smaller than the significance level (0.05), the zero assumption is rejected, and the claim that the class rank is similar cannot be accepted. 
Based on that, timely submission had the highest rank followed by timely payment of taxes and filing in the tax unit.

Table 14: Ranking of tax culture components in the studied population

\begin{tabular}{cccccl}
\hline value-p & $\begin{array}{c}\text { Degree of } \\
\text { freedom }\end{array}$ & Chi-square & Rank & Mean ranks & \multicolumn{1}{c}{ Dimensions } \\
\hline & & 3 & 1.81 & Filing in the tax unit \\
$0 / 000$ & 2 & $209 / 409$ & 1 & 2.16 & $\begin{array}{l}\text { Submission of the tax return on } \\
\text { time }\end{array}$ \\
& 2 & 2.03 & Timely payment of taxes \\
\hline
\end{tabular}

\section{Discussion and conclusion}

The findings of this study showed that according to the mean scores obtained, each of the components of the tax culture of the tax payers is more than satisfactory.

The ranking of the components of tax culture in the studied population was the "timly submission of tax returns", the "timely payment of taxes", and "filing in the tax unit", respectivly. Therefore, the research suggestions are as follows:

- Confidence building between tax authorities and taxpayers through holding reflection sessions.

- Strengthening Corporations and train them to promote tax culture among payers.

- Persuading taxpayers to pay taxes by using mass media.

- Promoting the importance of taxes by clerics and expressing tax debates and their necessity in the Islamic society and obligation of tax payment by the islamic scholars.

- Familiarizing tax payers with tax collection procedures, specifying tax collection procedures and easy access to tax laws.

- A clear and accurate description of employee policies, staff accountability and tax organization;

- Improving skills and experience in tax staff.

- Attention to the law on the ability to taxpayers' payment, heavy fines for offenders.

- The existence of tax punishments commensurate with the conduct of taxpayers, familiarity of tax brokers with tax laws.

- Familiarity of tax brokers with the process of collecting taxes.

- Participation of tax payers in successful performance in organization policies.

- Notification of spending taxes to the taxpayers.

References:

1- Bazargan, Abbas, Mousavi, Shahrokh, Malek, Farhad., Malek, Mojtaba, Babaei, Mehdi, Ghahramanfard, Farahnaz. And Hajjaghajani, Saeed. 1999. Internal evaluation, a process for improving the quality of 
medical education: Case study of Semnan university of medical sciences. Journal of Semnan University of Medical Sciences, Volume 1, Issue 2, Pages 11-18.

3- Shamsuddini, Mostafa, Shahraki, Javad. (2016). Investigating the Factors Affecting Tax Revenues in Iran. Economic Policy, 8 (15), 77-116.

4- Shadiya, Hakimeh (2007). Investigating the ways to promote tax culture in the department of jobs of the Ministry of Public Administration of West Tehran.

5- Salehi Mahdi, Parvizifard Saeed, Stewar Masoorah (2014) The Effect of Tax Cultures on Tax Compliance among Taxpayers. Tax Law Research; 22 (23)

6- Arami, Hassan (2005), The factors affecting the promotion of tax culture and collect taxes from employee tax administration Aran Bidgol city. "Tehran, Master's thesis.

7- Qilbawi, Gholamreza (2007); Tax culture and its review of the community of physicians in northern Tehran and presentation of behavioral analysis model.

8- Lashkarizadeh, Maryam; Azizi, Mohammad (2011) Identification of some effective factors on promoting tax culture in Iran, Researcher (Management): Summer 2011, Volume 8, Number 22; From page 82 to page 91.

9. Mahboobi, Ghorbanali, Shahbazi, Najaf Ali (2011). Taxation culture in Iran. Nursing for Cultural Engineering, August and September, No. 55 and 56. Pages 55-67.

10. Masihi, Mohammad; Mohammad Nejad, Abolqasem (2015). Investigating the Factors Affecting Tax Cultures in the Perspective of Taxpayers and Tax Experts of the General Directorate of Value Added Tax of Tehran, Cultural Management Quarterly, Bahar, No. 27. pp. 29-46.

11- Bame-Aldred, C. W., Cullen, J. B., Martin, K. D., \& Parboteeah, K. P. (2013). National culture and firm-level tax evasion. Journal of Business Research, 66 (3), 390-396.

12- Pickhardt, M., \& Prinz, A. (2014). Behavioral Dynamics of Tax Evasion - A Survey. Journal of Economic Psychology, 40, 1-19.

13- Litina, A., \& Palivos, T. (2016). Corruption, tax evasion and social values. Journal of Economic Behavior \& Organization, 124, 164-177. 